\title{
Epizootiology of Fascioliasis and its Public Health Implications in Some Communities Near University Of Port Harcourt, Rivers State, Nigeria
}

\author{
Wokem Gloria ${ }^{1 *}$ and Don Angel J ${ }^{2}$ \\ ${ }^{1}$ Department of Medical Laboratory Science, Rivers State University of Science and Technology, Nigeria \\ ${ }^{2}$ Department of Animal and Environmental Biology, University of Port Harcourt, Nigeria
}

Submission: September 15, 2017; Published: October 20, 2017

*Corresponding author: Wokem Gloria N, Department of Medical Laboratory Science, Faculty of Science, Port Harcourt, Nigeria, Email: g.ndrwokem@yahoo.com

\begin{abstract}
The epizootiology and public health implications of a neglected tropical zoonosis was investigated in three Communities within University of Port Harcourt Environment. A total of 712 cattle liver samples were examined for bovine fascioliasis, using standard parasitological methods for three months from three selected abattoirs in the study area. A well structured questionnaire also was used to assess the butchers' knowledge and attitudes to fascioliasis. Of the 114 liver samples examined in Choba abattoir in the first month, 42(36.8\%) were infected, prevalence in the second month was higher $48(40.7 \%)$ though not statistically significant $(\mathrm{p}<0.05)$. A total of 352 liver lobes were examined in Choba with an average infection rate of 134(38\%).Infection rates in Alakaha were, first month, 40(40.8\%), second month, 44(45.8\%) and third month, $42(44.7 \%)$ respectively with average prevalence of $126(43.8 \%)$ out of 288 samples. Highest infection rate at Rumuokparali abattoir was $14(58.3 \%)$ for second and third months, the least occurred in first month $4(16.6 \%)$ while the overall prevalence was $41 \%$. Out of 45 butchers interviewed, $36(80 \%)$ had acknowledged the liver-worm infection, $9(20 \%)$ did not know of it, none knew about the transmission dynamics whereas 35(77.8\%) would accept compensation and have the condemned carcasses destroyed, $8(17.8 \%)$ hated the idea, only $2(4.4 \%)$ were undecided. A host of factors influencing the transmission fasciolopsis include climatic conditions, attitudes of herdsmen, gross contamination of communities and pasture lands with droppings from infected cattle, non treatment of infected animals, uncontrollable grazing on farmlands by Fulani cattle herdsmen, ignorant, problem of poly-parasitism, non treatment of affluence from abattoirs before discharging into surrounding fresh-water bodies, butchers attitudes and poverty. Public enlightenment campaign, ranch system of animal rearing, incineration of condemned carcasses after compensation, and improved sanitary abattoir management will decline transmission and save impending danger of epidemic.
\end{abstract}

Keywords: Epizootiology; Fascioliasis; Abattoir; Public health importance; Uniport-community

\section{Introduction}

Fascioliasis is a systemic infection caused by the liver flukes, Fasciola gigantica and Fasciola hepatica [1]. They belong to the family Fasciolidae, members being typically leaf-shaped flukes. An adult $F$. hepatica measures $20-30 \mathrm{~mm}$ long and $13 \mathrm{~mm}$ broad while an adult $F$. Gigantic measures $25-75 \mathrm{~mm}$ long by $12 \mathrm{~mm}$ broad. The disease they both cause is similar [2].

Fascioliasis, tops all the zoonotic helminthiasis worldwide [3]. A large variety of animals, such as sheep, goats, cattle, buffalo, horses, donkeys, camels and, rabbits, show infection rates that may peak $90 \%$ in some areas [4]. The infection was endemiotopes in the past but is now widespread throughout the world, with human cases being increasingly reported from Europe, the Americas, Oceania and from Africa and Asia where the two species overlap [5]. Cattle get infested normally in the rainy season, but in the dry season, the herdsmen migrate in search of water and pastures such that thousands of cattle often converge on the few ponds that are perennial. In such locations, snail intermediate hosts are found which may reinforce the Fasciola infestation of more cattle in the rains [68]. Other factors which enhanced the spread of fascioliasis are contamination of water sources by human and nonhuman hosts and dietary practices that include the raw, untreated aquatic foliage located around water reservoirs [9-11]. Ruminant hosts become infected when forage with metacercariae is ingested. They can also be infected after ingesting metacercariae suspended in soil and detritus while drinking water. Ingested parasites find their way to intra hepatic biliary duct or hepatic parenchyma and later to the bile duct where they reside $[9,11]$. Infected ruminant usually experience traumatic injury giving 
rise to diffuse hepatic parenchyma containing haemorrhagic streaks or foci. The animal may experience weight loss, anaemia and general depression. The liver may be enlarged and show abnormal functions. Blood leucocytosis with eosinophilia in response to Cathepsin B (cat 12) antigen secreted by juvenile fluke may be observed. Complications due to synergy with Clostridium noryiand Clostridium haemolyticum result in black disease referred to as infectious necrotic hepatitis.

High rates of human infection have been found in Bolivia, Peru and Egypt, and this may be due to consumption of certain food [12]. Where it occurs sporadically, fascioliasis affects people from all age-groups and there is no specific risk group. Where the infection is highly endemic, the prevalence and intensity of infection tend to peak in school-age children. Fascioliasis is a global disease, and human cases have been reported from more than 75 countries worldwide. Recognized areas of high transmission are the 3Asia and south-east Asia. An estimated 2.4 million people in over 61 countries are infected annually with Fasciola spp with 180 million at risk of infection [13]. The epidemiological pattern of fascioliasis is quite varied: the infection usually has a hypo-endemic pattern, with low and stable levels of prevalence among a defined population. Sporadic outbreaks may occur among such populations: these are usually related to sudden changes in climatic conditions that boost the life-cycle of either the parasite or the snail, or both. In Africa and Asia, where both F. hepatica and F. gigantica are present, mixed infections are possible. In Asia, hybridization among the two species occurring in co-infected humans or animals has been described. The offspring resulting from such hybridization is characterized by intermediate morphological characteristics between the two species as well as by different ploidies (diploid, triploid, and mixoploid); such worms are frequently non-fertile [2]. Parasitological diagnosis using Kito Kat technique [14] and formal-ether sedimentation technique [15] are performed to detect Fasciola eggs in stool samples; their cost and sensitivity may vary according to the type used; they can only be employed in the chronic phase; some of them allow quantifying intensity of infection (WHO, electro transfer blot (ETIB) have been found to be the most sensitive and specific methods of diagnosis [16]. A number of countries are implementing control of fascioliasis through the use of triclabendazole. Proper abattoir operation and management including efficient inspection of live animal (ante-mortem) and the carcass (post-mortem) are crucial towards surveillance network for animal diseases and zoonoses as well as ensuring suitability of meat and it's by products for their proposed uses [17].

With the advent of global warming and the consequent climatic changes in the country, the Fulani cattle herdsmen, originally dwelling in the North, have in the recent times ravaged the Southeast Nigeria in discriminately in want of pasture for their animals, to the detriment of economic crops, lives, wealth and health of the south easterners. Sequel to the invasion, there has been gross contamination of farmlands, major roads, fresh water bodies, communities with droppings from cattle as they graze on any available pasture as they move on. The losses in terms of properties, economic crops and human lives destroyed during confrontations may be quantified but the psychological trauma, poly parasitism and poverty burdens cannot be easily quantified. World Health Organization measures diseases burden as Disability Adjusted Life Year (DALY) and this was used to calculate the Global Burden of the Disease estimate [18]. Torgerson and Macpherson, [19] summarized the possible global burden of zoonotic fascioliasis to be $>0.5 \times 106$, animal health cost was high while the trends were assessed as increasing. This work aimed at investigating the epizootiology and public health implications of bovine fascioliasis in three Communities near University of Port Harcourt Community and to advocate management strategies based on the findings.

\section{Study area}

Port Harcourt is the capital of Rivers State in Nigeria, West Africa. It lies along the Bonny River and is located in the Niger Delta Region. Its geographical coordinates are Latitude 47'21'N and Longitude 6 $6^{\circ} 9^{\prime} 54$ "E of the Equator. Port Harcourt features a tropical monsoon climate with lengthy and heavy rainy seasons and very short dry seasons. Only the months of December and January truly qualify to be considered as dry season although, with global warming, dry season extends to the month of March in recent times. The harmattan, which climatically influences many cities in West Africa, is less pronounced in Port Harcourt [20]. Port Harcourt's heaviest precipitation occurs during September with an average of $367 \mathrm{~mm}$ of rain. December is the driest month of the year with an average rainfall of $20 \mathrm{~mm}$. Temperatures throughout the year in the city are relatively constant, showing little variation throughout the course of the year. Average temperatures are typically between $25^{\circ} \mathrm{C}-28{ }^{\circ} \mathrm{C}$ in the city [12]. The three abattoirs selected for this study namely Rumuokparali, Choba and Alakahia abattoirs are located within communities surrounding University of Port Harcourt (Uniport) Rivers State, Nigeria.

\section{Study population}

According to the 2006 census, the Port Harcourt urban area has a population of 1,382,592 [12]. The study area is populated by residents who are traders, civil servants, academia, students, farmers and artisans. The demand for meat in Port Harcourt and Uniport Communities in particular is very high hence cows are slaughtered on daily basis.

\section{Sample collection}

Ethical clearance from the Department of Animal and Environmental Biology was tendered to Sanitary Inspectors, Veterinary Doctors while informed consent was obtained from the Head of the Butchers Association before liver samples were accessed for examination using standard parasitological methods. 
A total of 712 cattle liver samples were examined from three abattoirs closest to Uniport Community. This was done between 06:00am and 11:00am when sales were at the peak, for a three month period from October, 2015 to early January 2016.The cattle livers were visually inspected for the presence of gross lesions indicative of Fasciola infection. A metal hook and a knife were used to incise the liver samples for the presence of adult liver flukes. Palpation of liver lobes to cause the emergence of Fasciola species was also done wearing hand gloves. Upon discovery of liver flukes, they were collected and fixed in universal bottles containing $10 \%$ formalin; the ones used for morphological studies were not fixed. The butchers were interviewed assessing their awareness of fascioliasis and their attitudes towards it using a well structured questionnaire.

\section{Data analysis}

Data generated were further analysed statistically using Statistical Package for Social Sciences (SPSS) version 10 while probability value of 0.05 was considered significant.

\section{Results}

In Choba abattoir, 114 liver samples were examined in the first month having 42(36.8\%) infection, in the second month 118 livers were examined with $48(40.7 \%)$ infection rate while in the third month of the study, 120 were examined with $44(36.7 \%)$ infection rate (Figure 1). A total of 352 livers were examined in Choba with an average infection rate of $134(38 \%)$.

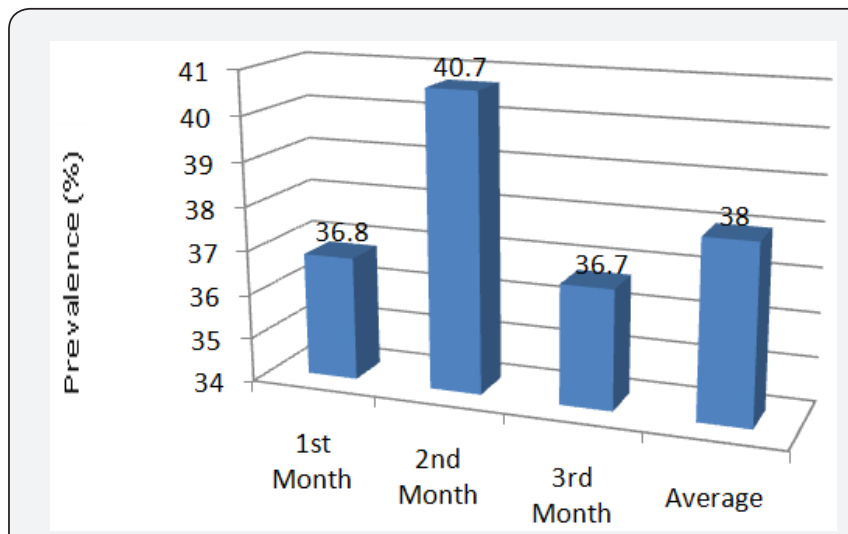

Figure 1: Prevalence of bovine fascioliasis in Choba abattoir per month.

In Alakahia, the first month 98livers were examined and $40(40.8 \%)$ were infected, in the second month, 96 were examined with an infection rate of $44(45.8 \%)$; in third month, 94 were examined with $42(44.7 \%)$ infected. The average infection rate in Alakahia abattoir was $126(43.8 \%)$ out of 288 sampled (Figure 2).

For Rumuokparali abattoir, 24 liver samples were examined in the first month with an infection rate of 4(16.6\%), 24 in the second month with an infection rate of $14(58.3 \%)$ and 24 in the third month with an infection rate of 14(58.3\%). In Rumuokparali abattoir, a total of 72 livers were examined with a mean infection $(44.4 \%)$ though the difference was not statistically significance $(\mathrm{p}=0.926)$. Out of the 712 livers sampled in the three locations, 292(41\%) were infected (Figure 3 \& 4).
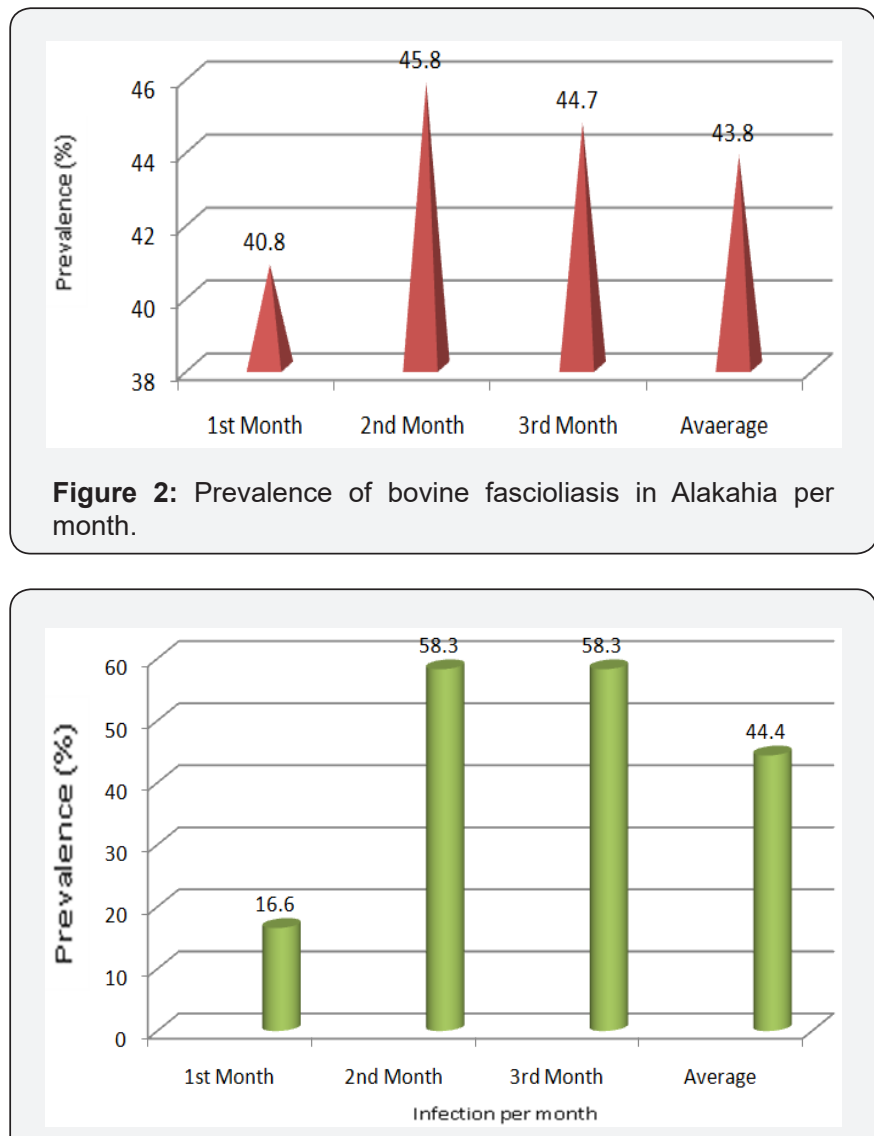

Figure 3: Prevalence of bovine fascioliasis infection in Rumuokparali abattoir per month.

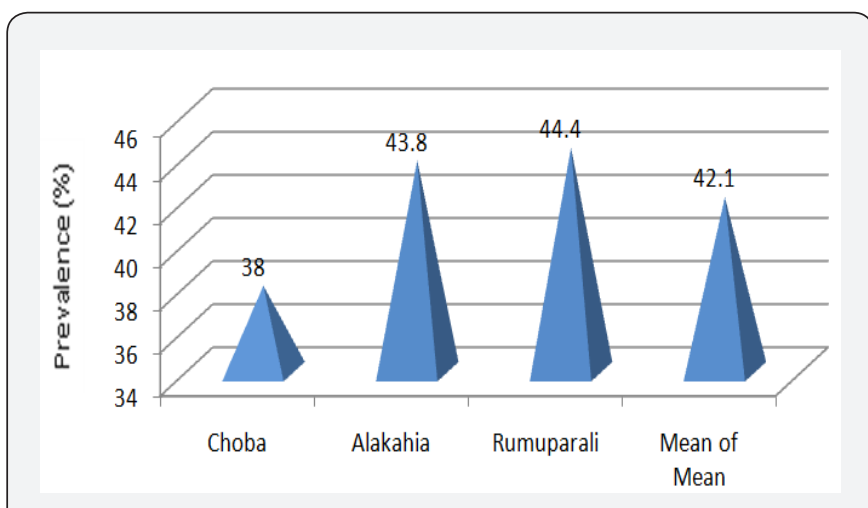

Figure 4: Average prevalence of bovine fascioliasis per location.

Table 1, shows attitude and knowledge of the butchers about the zoonosis. Out of 45 butchers interviewed with questionnaire, $36(80 \%)$ acknowledged it as liver-worm infection, 9(20\%) did not know, none knew about the transmission dynamics, $35(77.8 \%)$ were ready to hand over infected liver lobes if given compensation, $8(17.8 \%)$ were very aggressive on hearing compensation while only $2(4.4 \%)$ worked out indifferently. (Figure 5) Plate 1: shows the morphology of unfixed Fasciola hepatica extracted from cattle liver lobes. 
Table 1: Knowledge and attitudes of the butchers towards bovine fascioliasis in the study area.

\begin{tabular}{|c|c|c|c|c|c|}
\hline \multirow{2}{*}{ S1. No. } & \multicolumn{2}{|c|}{ Knowledge of No. Examined Fascioliasis N=45 } & \multicolumn{2}{c|}{ Response of Respondents } & No. Absconded \\
\cline { 3 - 6 } & Knowledge of the infection & 45 & $36(80)$ & $9(20)$ & $0(0)$ \\
\hline 1 & Transmission dynamics & 45 & $0(0)$ & $0(0)$ & $0(0)$ \\
\hline 2 & Readiness for compensation & 45 & $35(77.8)$ & $8(17.8)$ & $2(4.4)$ \\
\hline
\end{tabular}

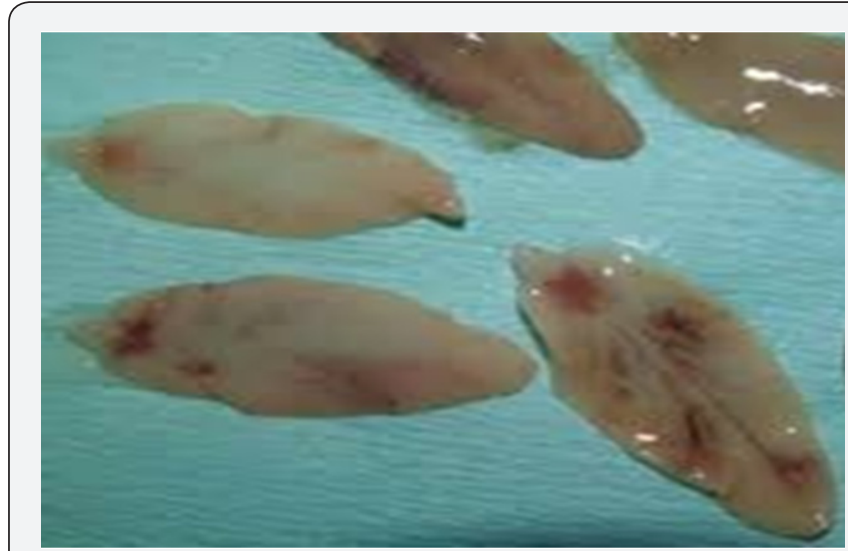

Figure 5: Plate 1: Fresh Liver flukes extracted from samples (Fasciola hepatica) $\times 3$.

\section{Discussion}

The results of this study clearly indicate the presence of bovine fascioliasis in the abattoirs of choice. The prevalence of fascioliasis in the first month of the study in Choba abattoir was the least, it peaked in the second month followed by the third month although, the difference was not statistically significant $(\mathrm{P}>0.05)$. The pattern of infection in Alakahia abattoirwas similar to that in Choba. In Rumuokparali abattoir, where fewer cattle were being slaughtered, $16.6 \%$ of the cattle slaughtered suffered the infection in the first month, in the second and third months, each recorded $58.3 \%$ infection rate, the difference between the first prevalence rate and that of the second and the third month was statistically significant $(\mathrm{p}<0.05)$. The sample size may have contributed to the observation. These results agree with the report of Torgerson \& Claxton [21] who claimed that fascioliasis impacts a major burden on livestock industries and that many endemic countries have high livestock prevalence often with more than $50 \%$ of animals infected. However, the average prevalence in the study area ranged from $38 \%$ to $44.4 \%$ which is not in agreement with earlier report from Magaji et al. [4], that bovine fascioliasis infection rates can be as high as even $90 \%$ in some geographical areas. However, it seems, the results of this investigation are like an iceberg in the sea. If there are no high standards of veterinary public health that will limit transmission to humans, epidemic will soon erupt in the southern Nigeria, Uniport inclusive. It has been proved that strong correlation does exist between human and animal prevalence in same region [13]; earlier researchers, [22] reported that 91.1million people are living at the risk of fascioliasis. In the current study area the influencing factors, include improper screening of animals' health status before slaughter, gross contamination of our roads and pasture lands with droppings from already infected cattle, non treatment of infected animals, uncontrollable grazing in farmlands in Port Harcourt, including the University of Port Harcourt communities and other neighbouring States by Fulani cattle herdsmen, ignorance of transmission dynamics of the parasite, increased human exposure rates to the infective stage of the fluke, problem of poly-parasitism, and discharge of untreated affluence from abattoirs into surrounding fresh-water bodies. Again, the unique moist climatic condition of Rivers State makes it a paradise for water and food-borne diseases. With fascioliasis gaining more prominence as a neglected tropical zoonosis [22], particularly in Nigeria, if no action plan is done to reduce its transmission, it is likely to get to an epidemic level; then children, farmers, low-income earners and students' populace are likely to be at risk more, based on their age and lifestyles.

With the global economic recession and consequent hardship, the butchers in this study, seemed not to appreciate any reason to bear the massive economic burden of disposing infected carcases, although, they were aware that these organs were not fit for human consumption. Earlier researchers in Ethiopia [22] had estimated that the zoonosis causes significant economic losses of over 3 billion US dollar to livestock sector. If there will be ameliorating polices from the Government, encouraging financial compensation of butchers fully or partly for the economic losses incurred as a result of fascioliasis while the infested organs are withdrawn for destruction; that will help reduce not only its transmission but other zoonosis hence more than $70 \%$ of the butchers were ready to cooperate with a promise of compensation. On the other hand, the poor income earners who are tempted to buy the spoilt organs simply because they are cheaper will not have access to these infested cheaper meat. A slaughter house is a key component of the production and distribution chain for meat and as such, should be as hygienic as possible, in order to reduce the spread of zoonosis, and to reduce economic losses according to Erick et al. [23]. It has also been reported that many abattoirs and slaughter slabs in developing countries are poorly constructed with poor slaughter and meat inspection facilities, as well as lacking qualified meat inspectors [24]. This depicts the picture of these abattoirs, though sited in a University Community, yet they lack standard abattoir facilities; 
most importantly, hygienically built slabs with good drainage system. If the runoffs and wastes from the slaughter should be treated before discharging into the surrounding water bodies to ensure the destruction of parasite eggs and cercariae that will in turn significantly decline the transmission even though the intermediate snail hosts are in abundance.

The prevailing climatic conditions are also another major contributory factors. Humid warm conditions in the main cattle rearing areas are conducive for the survival of the aquatic snails that act as the intermediate host of Fasciola spp. It is recommended that prompt chemotherapy of live animals with improved meat inspection and incineration of infested carcasses will control not only fascioliasis but other helminthiasis like cysticercosis, hydatidosis and other neglected tropical parasitic diseases of public health importance. Finally, the Government introduction of ranch-system policy for rearing of animals will contribute significantly in environmental pollution control in addition to minimizing communal clashes that normally lead to wanton destruction of lives and properties in Nigeria. Again, the use of ranch system allows the herdsmen to quarantine infested animals for effective chemotherapy. The control of snail intermediate hosts is cumbersome, capital intensive, time consuming and skill demanding with minimal results compared to the resultant output of getting to use ranch system. Mass education and public health enlightenment through social medial and slogans on bill boards will be good control tools.

\section{References}

1. Egbu FMI, Ubachukwu PO, Okoye IC (2013) Haematological changes due to bovine fascioliasis. African Journal of Biotechnology 12(15): 1828-1835

2. (2015) World Health Organization.

3. Haridy FM, Morsy TA, Gawish NI, Antonios TN, Gawad AAG (2002) The potential reservoir role of donkeys and horses in zoonotic fascioliasis in Gharbia Governorate, Egypt. J Egypt Soc Parasitol 32(2): 561-570.

4. Magaji AA, Ibrahim K, Salihu MD, Saulawa MA, Mohammed AA, et al. (2014) Prevalence of Fascioliasis in Cattle Slaughtered in Sokoto Metropolitan Abattoir, Sokoto, Nigeria. Advances in Epidemiology 2014(2014): 5.

5. World Health Organization (2007) Report of the WHO informal meeting on use of triclabendazole in fascioliasis control. WHO headquarters, Geneva, Switzerland, pp. 1-39.

6. Odigie BE, Odigie JO (2013) Fascioliasis in cattle: A survey of abattoirs in Egor, Ikpoba-Okha and Oredo Local Government Areas of Edo State, using histochemical techniques. International Journal of Basic, Applied and Innovative 2(1): 1-9.

7. Adebowale OAL (2012) Dynamics of ruminant livestock management in the context of the Nigerian agricultural system. Agricultural and Biological Sciences 4: 61-62.
8. Adedokun OA, Ayinmode AB, Fagbemi BO (2008) Seasonal prevalence of Fasciola gigantica infection among the sexes in Nigerian cattle. Veterinary Research 2(1): 12-14.

9. Abraham JT, Jude IB (2014) Fascioliasis in cattle and goat slaughtered at Calabar abattoirs. Journal of Biology, Agriculture and Healthcare 4(18): 34-40.

10. Nyindo M, Lukambagire AH (2015) Fascioliasis: An ongoing zoonotic trematode infection. Biomed Res Int 2015: 1- 8.

11. Wokem GN, Abah AE, Sounya II (2017) Histopathological effect of Fascioliasis infection in goats slaughtered in three abattoirs in Port Harcourt Metropolis, Rivers State, Nigeria. Current Trends in Biomedical Engineering \& Biosciences 8(4): 555742.

12. Wikipedia (2015) Fascioliasis.

13. Parkinson M, O'Neil SM, Dalton JP (2007) Endemic human fasciolosis in the Bolivian Altiplano. Epidemiol Infect 135(4): 669-674.

14. Cheesbrough M (2005) District Laboratory Practice in Tropical Countries. In: Cheesbrough M (Ed.), Tropical Health Technology. ( $2^{\text {nd }}$ edn), Cambridge University Press, UK, pp. 267- 380.

15. Uga S, Tanaka K, Iwamoto $N(2010)$ Evaluation and modification of the formalin-ether sedimentation technique. Trop Biomed 27(2): 177-184.

16. Hillyer GV, de Galanes MS, Perez JR, Bjorland J, de Lagrava MS, et al. (1992) Use of the Falcon assay screening test-EnzymeLinked Immunsorbent Assay (fast-ELISA) and the Enzyme-linked Immunoelectrotransfer Blot (ET1B) to determine the prevalence of human Fascioliasis in the Bolivian Altiplano. Am J Trop Med Hyg 46(5): 603-609.

17. Nwanta JA, Onunkwo JI, Ezenduka VE, Phil-Eze PO, Egege SC (2008) Abattoir operations and waste management in Nigeria: A review of challenges and prospects Sokoto Journal of Veterinary Sciences 7(2): 65-72.

18. Lopez AD, Mathers CD, Ezzati M, Jamison DT, Murray CJL (2006) Global Burden of Disease and Risk Factors. In: Lopez AD, Mathers CD, Ezzati M, Jamison DT, Murray CJL (Eds.), Disease Control Priorities Project. The International Bank for Reconstruction and Development/The World Bank, Oxford University Press, Washington DC, New York, USA, p. 478.

19. Torgerson PR, Macpherson CN (2011) The socioeconomic burden of parasitic zoonoses: global trends. Vet Parasitol 182(1): 79-95.

20. The weather Network (2014) Port Harcourt.

21. Torgerson PR, Claxon J (1999) Epidemiology and control. In: Dalton PR (Ed.), Fasciolosis. CAB International, Oxford, England, UK, pp. 113-149.

22. Mahenddra P, Mukarim A, Mesfin Z (2014) Growing significance of fascioliasis as an emerging zoonosis. Ethiopian International Journal of Multidisciplinary Research 1(4): 10-13.

23.Komba EV, Komba EV, Mkupasi EM, Mbyuzi AO, Mshamu S, et al. (2012) Sanitary practices and occurrence of zoonotic conditions in cattle at slaughter in morogoro municipality, tanzania: implications for public health. Tanzan J Health Res 14(2): 131-138.

24. Biu AA, Ahmed MI, Msheila SS (2006) Economic assessment of losses due to parasitic diseases common at the Maiduguri abattoir, Nigeria. African Scientist 7(3): 143-145. 
(C) Commons Attribution 4.0 License

BY DOI: $10.19080 / C T B E B .2017 .09 .555770$
Your next submission with Juniper Publishers will reach you the below assets

- Quality Editorial service

- Swift Peer Review

- Reprints availability

- E-prints Service

- Manuscript Podcast for convenient understanding

- Global attainment for your research

- Manuscript accessibility in different formats

( Pdf, E-pub, Full Text, Audio)

- Unceasing customer service

Track the below URL for one-step submission https://juniperpublishers.com/online-submission.php 